\title{
Rancang Bangun Mesin Penggiling Kotoran Kambing dengan Sudu Berbentuk Martil
}

\author{
Kuni Nadliroh \\ Program Studi Teknik Mesin, Universitas Nusantara PGRI Kediri \\ E-mail:kuninadliroh@unpkediri.ac.id
}

\begin{abstract}
Abstrak
Pupuk merupakan kebutuhan fundamental bagi para penduduk Indonesia dengan mayoritas pekerjaan penduduknya sebagai petani. Pupuk yang mereka gunakan biasanya berupa pupuk kimia dari pabrik atau pupuk kompos yang mereka olah sendiri maupun pupuk kandang. Penggunaan pupuk pabrik yang terus menerus bisa mengakibatkan rusaknya tanah akibat ketidak seimbangan pH tanah, sedangkan penggunaan pupuk kandang yang alami bisa menyeimbangkan pH sehingga tanah akan tetap terjaga kesuburannya. Pupuk kandang merupakan pupuk yang berasal dari kotoran hewan yang biasanya hanya dibiarkan dalam beberapa waktu tertentu sehingga setelah kotoran tersebut berubah bentuk menjadi serbuk yang menyerupai tanah baru kemudian diaplikasikan kepada tanaman. Proses perubahan kotoran hewan menjadi serbuk membutuhkan waktu yang lama, terlebih lagi kotoran kambing yang mempunyai bentuk yang bulat dan keras, untuk berubah menjadi serbuk diperlukan waktu bertahun-tahun, maka dari itu diperlukan alat untuk mengolah kotoran kambing tersebut menjadi serbuk dengan bentuk sudu seperti martil dengan ukuran sudu panjang $7 \mathrm{~cm}$ dengan diameter sudu $6 \mathrm{~mm}$ sehingga proses penggilingan diasumsikan seperti pemukulan berulang-ulang terhadap kotoran kambing supaya bisa segera digunakan oleh para petani untuk proses pemupukan.
\end{abstract}

Kata Kunci: mesin, kotoran hewan, $\mathrm{pH}$ tanah, pupuk

\section{Abstract}

Fertilizer is a fundamental need for Indonesian residents with the majority of the population working as farmers. The fertilizers they use are usually in the form of chemical fertilizers from factories or compost that they treat themselves or manure. Continuous use of factory fertilizers can cause damage to the soil due to imbalance in soil $\mathrm{pH}$, while the use of natural manure can balance $\mathrm{pH}$ so that the soil will remain intact. Manure is a fertilizer derived from animal manure which is usually only left in a certain amount of time so that after the impurities are transformed into powder which resembles new soil then applied to plants. The process of changing animal manure into powder takes a long time, moreover goat manure which has a round and hard shape, to turn into powder takes years, therefore a tool is needed to process the goat manure into powder with a blade shape such as a hammer with length $7 \mathrm{~cm}$ and diameter $6 \mathrm{~mm}$ so that the grinding process is assumed to be like a repeated beating of goat manure so that farmers can use it immediately for fertilization.

Keywords: machine, animal waste, soil pH, fertilizer

Diterima 23 Juli 2019; direvisi terakhir 25 Juli 2019; diterbitkan 29 Juli 2019 


\section{PENDAHULUAN}

Masyarakat Indonesia merupakan masyarakat yang penduduknya sebagian besar mempunyai mata pencaharian sebagai petani, akan tetapi keadaan luas lahan yang semakin berkurang mengakibatkan para petani untuk lebih jeli dalam hal pengolahan lahan pertanian mereka, hal yang telah terjadi saat ini adalah banyaknya tanah yang tandus, mempunyai tekstur keras sehingga menahan akar untuk bergerak bebas dalam rongga tanah [1]. Fenomena gagal panen menjadi hal yang ditakutkan bagi seluruh lapisan petani, ada beberapa penyebab gagal panen yang dialami petani, yang pertama adalah kekeringan, kekeringan yang panjang menyebabkan pasokan air untuk tanaman berkurang meskipun telah dilakukan penambahan volum air melalui aliran air dari sungai maupun sumur pompa masih mengalami kekurangan, selain masalah air terdapat juga masalah hama, masalah hama ini dapat di atasi dengan menyemprotkan pestisida ke tanaman, kemungkinan yang terakhir adalah tidak seimbangnya kadar $\mathrm{pH}$ tanah, tidak seimbangnya kadar $\mathrm{pH}$ tanah dimungkinkan karena konsumsi pupuk kimia yang berlebih sehingga menjadikan kondisi tanah terlalu asam [2], keadaan tanah yang kurang subur mengakibatkan tanaman tidak dapat tumbuh subur bahkan dimungkinkan tidak bisa tumbuh, untuk mengembalikan kesuburan tanah bisa dilakukan dengan penghentian sementara penenanaman, dalam tahap penghentian tanam ini dilakukan penanganan kusus terhadap lahan rusak, biasanya para petani melakukan pencangkulan yang dimaksudkan membalikkan posisi tanah yang semula ada di bawah berubah menjadi di atas dengan mencampurkan pupuk non kimia misalnya kotoran hewan ataaupun komos. kotoran hewan dan kompos di sini sebagai penyeimbang $\mathrm{pH}$ tanah sehingga $\mathrm{pH}$ tanah seimbang dan tanah kembali normal dengan tingkat kesuburan tertentu. tidak semua kotoran hewan bisa digunakan secara langsung untuk membantu proses penyeimbangan $\mathrm{pH}$ tanah, sebagai conth kotoran ayam dan kotoran sapi mempunyai $\mathrm{pH}$ yang lebih tinggi dibandingkan $\mathrm{pH}$ kotoran kambing sehingga pemberian kotoran ayam dan sapi secara langsung dapat membuat $\mathrm{pH}$ tanah menjadi basa, penggunaan kotoran sapi dan ayam harus dicampur dengan tanah supaya bisa digunakan sebagai penyeimbang $\mathrm{pH}$ tanah. selain kotoran ayam dan kotoran sapi yang bisa digunakan untuk membantu penyeimbangan $\mathrm{pH}$ tanah yaitu kotoran kambing, kotoran kambing mempunyai $\mathrm{pH}$ yang mampu membentuk 
tanah pada kondisi pH sekitar 6,0-6,5 [3] dan dapat digunakan secara langsung tanpa harus mencampur dengan tanah, akan tetapi kotoran kambing mempunyai kekurangan teksturnya yang keras sehingga jika ditambahkan pada tanah atau pada tanaman akan sulit terurai, untuk mengatasi hal tersebut diperlukan suatu alat yang bisa digunakan untuk merubah tekstur kotoran kambing menjadi serbuk. Pada umumnya para petani menggunakan cara manual untuk membuat kotoran kambing tersebut menjadi serbuk, yaitu dengan cara menempatkannya ke dalam karungkarung dan menyiramnya setiap hari sehingga dalam beberapa waktu kotoran kambing tersebut akan membusuk sehingga hancur dengan sendirinya, akan tetapi cara ini mempunyai beberapa kekurangan, diantaranya adalah membutuhkan waktu yang lama dan menimbulkan bau ke lingkungan sekitar akibat dilakukannya penyiraman yang terus menerus pada kotoran kambing, selain itu kotoran kambing ini memerlukan tempat yang teduh selama proses perubahan bentuknya sehingga dinilai tidak efisien dalam hal tempat penyimpanan.

Terdapat penelitian terdahulu mengenai alat yang digunakan untuk menghancurkan kotoran kambing, akan tetapi pada alat ini penghancurnya menggunakan roler yang dipasang sejajar sehingga sampel akan dipress dan dalam hal ini kotoran kambing akan berubah bentuk menjadi pipih tidak dalam bentuk serbuk sehingga perlu waktu yang relatif lama untuk hancur dan berbaur dengan tanah supaya kotoran kambing tersebut bisa bekerja sebagai pupuk [4], melihat hal ini maka perlu pengulangan lebih banyak untuk menjadikan kotoran kambing menjadi serbuk, sehingga dalam penelitian ini dilakukan variasi bentuk sudu dengan bentuk sudu yang menyerupai martil seingga dalam perlakuannya kotoran kambing dipukul sehingga berubah bentuk menjadi serbuk.

Kotoran kambing yang telah berubah bentuk menjadi serbuk akan lebih mudah dibaurkan dengan tanah sehingga lebih cepat dalam penyerapan zat yang diperlukan oleh tanaman dan tanah, selain itu bentuk kotoran kambing yang belum menjadi serbuk jika dibaurkan dengan tanah maka kotoran tersebut akan mudah berpindah pada tepatnya sebelum kotoran tersebut digunakan oleh tanaman.

Selain bisa digunakan langsung untuk pemupukan tanaman kotoran kambing bisa digunakan sebagai bahan pembuatan pupuk kompos dari sampah [5], tentunya penggunaan kotoran kambing yang telah berbentuk serbuk akan membantu dalam 
proses pembusukan sampah yang telah dikeringkan. penggunaan pupuk kompos tentunya akan memberikan banyak keuntungan dalam dunia pertanian, selain pupuk kompos tersebut ramah lingkungan juga kita tidak perlu mengeluarkan biaya yang mahal untuk mendapatkan pupuk kompos, selain itu dengan dibuatnya pupuk kompos maka sampah yang berada di lingkungan kita akan berkurang sehingga bisa dikatakan bahwa penggunaan kompos selain berguna untuk pertanian maka kompos berguna juga untuk kebersihan lingkungan. Selanjutnya selain digunakan untuk pemupukan tanaman secara langsung dan sebagai bahan pembuatan pupuk kompos, kotoran kambing juga bisa digunakan sebagai penyubur tanah yang telah tandus. Tanah yang tandus mempunyai tekstur yang padat, jika dilakukan pencangkulan dalam hal ini pembalikan posisi tanah atas dan bawah dan proses tersebut dibarengi dengan penambahan kotoran kambing yang telah menjadi serbuk maka tanah yang tandus tersebut akan kembali berongga dan mampu menyerap air dan unsur lain dari kotoran kambing yang bisa mendukung pertumbuhan tumbuhan. Proses pembolak balikan tanah atau pencangkulan tanah ini pada umumnya dilakukan sebanyak tiga kali pengulangan, tahap pertama dicangkul dan ditambahkan serbuk kotoran kambing dan kemudian dibaurkan, setelah itu diulangi tahap tersebut sebanyak tiga kali.

\section{METODE PENELITIAN}

Penelitian ini bersifat pembuatan dan uji coba alat, adapun alat serta bahan yang digunakan dalam penelitian ini adalah:
a. mesin disel
b. plat penutup $40 \mathrm{~cm} \times 40 \mathrm{~cm}$
c. pen penyangga sudu
d. baja untuk sudu
e. baja panjang untuk sudu
f. besi penyaring di bawah sudu $12 \mathrm{~mm}$
g. plat baja untuk corong
h. plat baja kanan kiri sudu
i. sepasang roda
j. pegangan mesin 

k. baut
1. belt
m. alat las

Adapun tahapan penelitian ini adalah:

Melakukan perancangan dan perakitan alat seperti gambar di bawah ini:

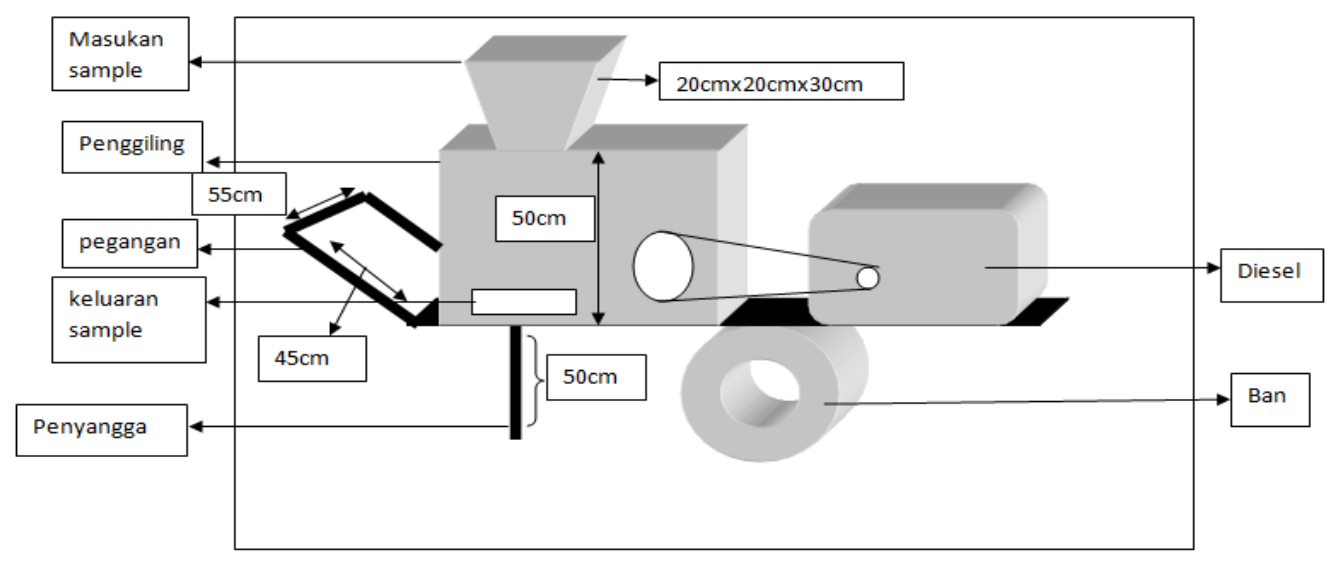

Gambar 1. Rancangan alat

Alat yang dirancang adalah satu set alat penggilingan yang terdiri dari:

1. Tempat masukan sampel

2. Wadah penggilingan

3. Tempat keluaran sampel

4. Rangka penggilingan lengkap dengan alat pegangan, penyangga, dan tempat untuk roda dan disel.

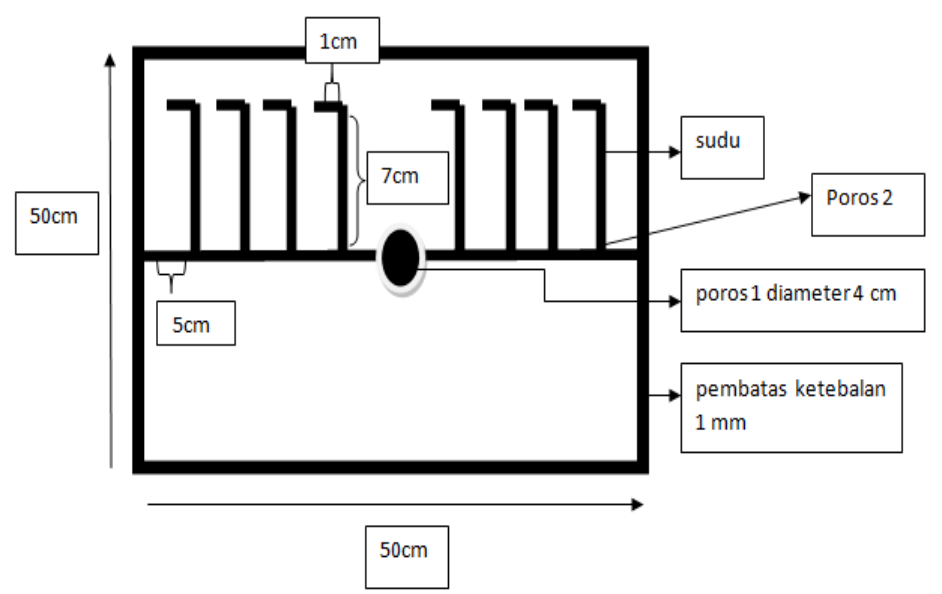

Gambar 2. Skema bentuk penggilingan dan ukurannya 


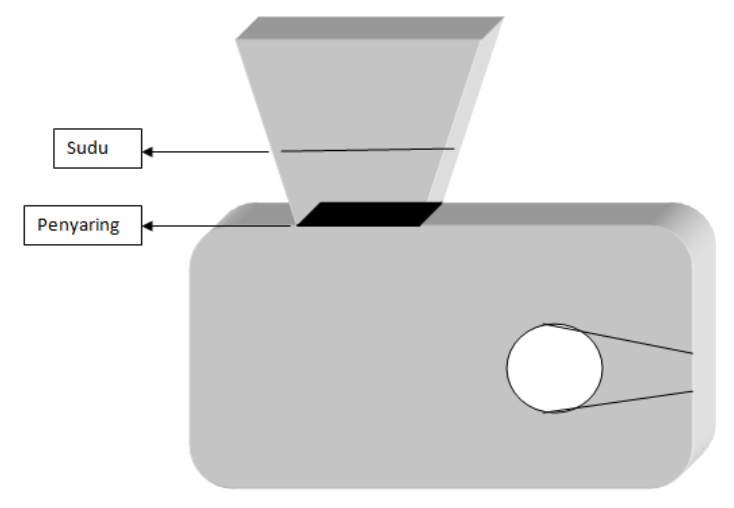

Gambar 3. Skema posisi sudu dan penyaring

Setelah selesai perakitan alat, kemudian dilakukan uji coba alat.

\section{HASIL DAN PEMBAHASAN}

Adapun alat yang dibuat dalam penelitian disajikan dalam gambar di bawah ini:

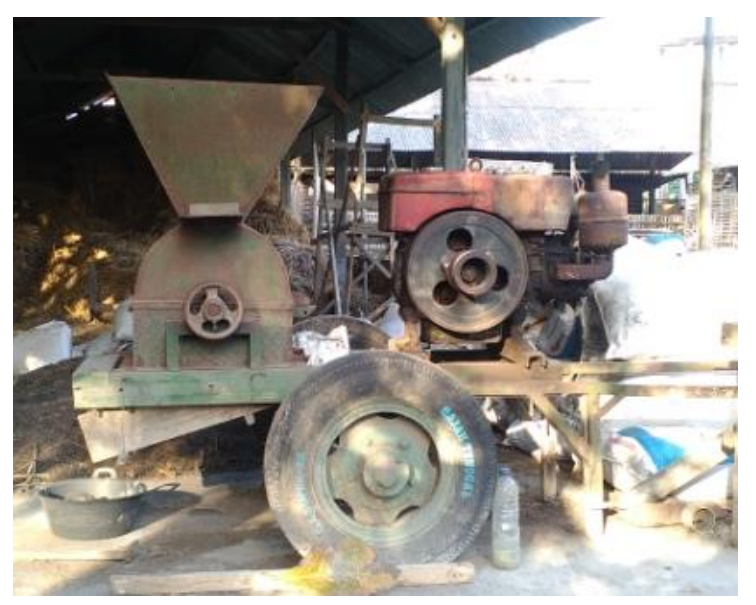

Gambar 3. Mesin hasil penelitian

Setelah dilakukan perakitan alat penelitian dan uji coba alat maka didapatkan bahwa alat ini mampu menghaluskan $25 \mathrm{~kg}$ kotoran kambing dalam waktu 20 menit.

Cara kerja alat ini adalah sebagai berikut:

Langkah pertama adalah menyalakan mesin, dimana dalam alat ini digunakan mesin disel sebagai sumber energi penggerak sudu, sedangkan penghubung antara mesin disel dengan alat utama (penggerak sudu) maka digunakan belt, setelah alat siap digunakan maka sampel kotoran kambing dimasukkan ke dalam corong (dalam hal ini bisa dimasukkan langsung sebanyak $25 \mathrm{~kg}$ ataupun sedikit demi sedikit), 
setelah sampel dimasukkan ke dalam corong maka penutup corong dipasang supaya sampel tidak tumpah keluar, selanjutnya sampel bergerak ke ruang sudu dimana dalam ruang ini kotoran kambing dilakukan perlakuan seperti ditumbuk, saat penumbukan dengan sudu berbentuk martil berlangsung maka sampel yang telah berubah menjadi serbuk jatuh menuju penadah yang berada di bawah sudu sedangkan sampel yang masih berupa butiran dan yang masih belum sempurna halus akan kembali ditumbuk oleh sudu berbentuk martil sehingga sampel tersebut berubah menjadi serbuk, untuk memisahkan sampel yang telah halus dengan sampel yang masih perlu dilakukan penumbukan maka di bawah ruang sudu dipasang penyaring dengan ukuran $12 \mathrm{~mm}$. Sampel sebanyak $25 \mathrm{~kg}$ akan dihaluskan oleh mesin ini dengan menggunakan waktu kurang lebih 20 menit. Adapun hal yang membedakan alat ini dengan mesin penggiling otoran kambing yang lainnya adalah:

1. Daya tampung lebih banyak.

2. Cepat dalam proses penghancuran karena menggunakan sudu berbentuk martil, yaitu membutuhkan waktu 20 menit tiap $25 \mathrm{~kg}$ sampel.

3. Sampel kotoran kambing tidak perlu dilakukan perlakuan terlebih dahulu, misalnya direndam air supaya lebih lunak sampel tidak tumpah sewaktu dilakukan proses penggilingan dikarenakan terdapat papan seng yang menutup bagian corong tempat sampel dimasukkan.

4. Bisa dipindahkan dengan mudah karena dilengkapi dengan roda sehingga memudahkan pekerjaan para petani.

Selain mempunyai kelebihan di atas alat ini mempunyai kekurangan diantaranya adalah menimbulkan bunyi yang keras, sehingga perlu dilakukan peredaman terhadap bunyi yang dihasilkan. Bunyi keras tersebut berasal dari bunyi sudu yang bergerak saat mesin berputar. Sudu dalam alat ini diposisikan bisa berputar pada dua keadaan, keadaan yang pertama berputar pada porosnya sedangkan keadaan yang kedua adalah berputar terhadap pengait pada sudu. Pada poros terdapat sudu utama yang berbentuk lurus, hanya berupa besi melintang sedangkan sudu yang berbentuk martil dipasangkan pada sudu utama dengan jumlah sudu dalam setiap sudu utama adalah 4 buah sudu, sehingga total sudu yang digunakan sebanyak 8 sudu. 
Seluruh badan dan kerangka yang digunakan pada alat ini adalah baja, hal ini dikarenakan bahwa untuk memproduksi kotoran kambing bentuk serbuk dalam jumlah yang banyak menggunakan alat besar yang kuat dan kokoh, selain itu penggunaan baja juga lebih tahan terhadap suhu dingin maupun suhu panas serta hujan.

Alat ini menggunakan sampel kotoran kambing kering, sehingga petani tidak perlu melakukan pembusukan terlebih dahulu seperti yang dilakukan petani pada umumnya pada saat proses pembuatan pupuk dari kotoran kambing, penggunaan sampel yang kering tersebut tidak menimbulkan bau busuk dan juga meminimalisir tenaga petani dan memangkas waktu untuk proses pembusukan kotoran. Pada alat ini hasil dari penggilingan kotoran kambing bisa langsung masuk ke dalam karung dan siap untuk digunakan.

\section{KESIMPULAN}

Dari alat yang telah dibuat dengan menggunakan bentuk sudu menyerupai martil dengan ukuran panjang $7 \mathrm{~cm}$ dan diameter sudu $6 \mathrm{~mm}$ dapat menghancurkan kotoran kambing dengan halus, untuk sampel kotoran kambing $25 \mathrm{~kg}$ membutuhkan waktu 20 menit sehingga dapat disimpulkan bahwa peralatan tersebut layak digunakan dengan melihat berbagai keuntungan yang ditawarkan melalui alat ini. Dengan menggunakan peralatan ini pekerjaan petani menjadi lebih mudah dalam hal pengolahan pupuk kandang yang akan diberikan kepada tanaman sehingga penggunaan pupuk kimia bisa dikurangi untuk menjaga kadar $\mathrm{pH}$ tanah dalam rentang 6 sampai 6,5 supaya tetap subur dan menghasilkan produk pertanian yang melimpah. selain menawarkan beberapa keunggulan alat ini juga mempunyai kekurangan yaitu menimbulkan bunyi yang keras sehingga menimbulkan polusi bunyi.

\section{DAFTAR PUSTAKA}

[1] Hanafiah, Kemas Ali. Dasar-dasar Ilmu Tanah. Jakarta: Raja Grafindo Persada. 2005.

[2] Prabowo, R. "Kajian Biopestisida dan Pupuk Hayati Dalam Mendukung Pengelolaan Tanaman Tomat Secara Terpadu”. Jurnal Mediagro. Vol. 4, No.1. 2008. 
[3] Sutedjo, M. M. Pupuk dan Cara Pemupukan. Rineka Cipta, Jakarta. 2002.

[4] Tri Dimas, dkk. "Rancang Bangun Mesin penggiling Kotoran Kambing". Skripsi, ITS, Surabaya. 2017.

[5] Muhammad A Trisna, Zaman Badrus. Pengaruh Penambahan Pupuk Kotoran Kambing Terhadap Hasil Pengomposan Daun Kering di TPST UNDIP. Jurnal Teknik Lingkungan, Vol. 6, No. 3. 2017. 